\title{
Dimension stones of the Old City Wall of Cluj-Napoca, Romania - an overview on history, mapping, weathering, and damages
}

\author{
Paul Calin RĂCĂTĂIANU* \& Roman KOCH
}

GeoZentrum Nordbayern, Friedrich-Alexander University Erlangen-Nuremberg, Applied Sedimentology and Building Stones Research, Loewnichstr. 28, D - 91054, Germany

Received February 2009; accepted May 2009

Available online June 2009

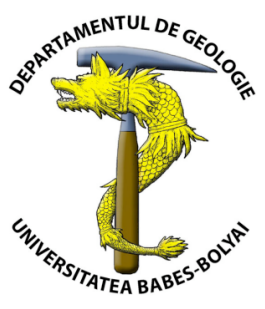

\begin{abstract}
The dimension stones used in the construction of the Old City Wall of Cluj-Napoca, Romania are Eocene limestones, which were quarried in close vicinity of Cluj. Different facies types reveal different weathering features. The weathering processes are complex and the weathering features vary markedly depending on the rock types, composition, weather conditions, geographical position, moisture/dry cycles, position in the building, and exposure to pollutants. The internationally accepted non-destructive method of mapping conjunctively with the new method of determining the "damage indices" allow a precise classification and evaluation of the rock types and damages and also an overview on the development of the damages in time.
\end{abstract}

Key words: weathering, damage, building stones, mapping

\section{INTRODUCTION}

Natural building stones have been used in the construction of the buildings, walls, and monuments since ancient times. Inevitably, these stones are exposed to several complex weathering processes, which result in the physical degradation of these structures. This paper presents an overview on the dimension stones used in the building of the Old City Wall of Cluj-Napoca, Romania. A short overview on the wall history is a prerequisite for understanding the importance of this edifice, construction, and localization. The paper will present the techniques and the models used for indexing of the rocks and damages, the weathering processes, the macroscopic and microfacies analyses of the building stones and the microscopic analyses of the mortars combined with mineralogical investigations.

\section{HISTORY}

The first documentation of a settlement within the area of modern Cluj was presented by the Greek geographer Claudius Ptolemeus, and mentioned as one of the most important localities of the Roman Dacia, Napuca. Shortly after the Roman conquest, 101-102 and 105-106 A.D., Napuca was destroyed and a new urbane locality (civitas), named Napoca, was built on the right side of the Samus (Someş) River. The archaeological discoveries established the accurate shape of the old Roman Napoca city to a great extent (Fig. 1). A new medieval fortification was built during the $9^{\text {th }}-10^{\text {th }}$ centuries and only a small relic "Castrum Clus" remained, which covered just a quarter of the original area of the Roman fortress (Fig. 1). After the decimation of the Cluj inhabitants during Tartars invasions, large groups of Transylvanian Saxons settled in the Cluj Fortress during the reign of King Stephan V of Hungary. The royal fortress "Castrum Cluj" developed an urbane organization within the $15^{\text {th }}$ century. During the same time, the city received the right to build its own defence walls, bastions and defence towers. Thus, construction of the City's Defence Wall began and it was continued till the end of the $16^{\text {th }}$ century.

\section{TECHNICAL DESCRIPTION}

The area of the new fortress ( $45 \mathrm{ha}$ ) was almost double in comparison with the first medieval fortress (Fig. 1). Specific for the region and for the medieval times are the city walls with loop-holes, built exclusively from stones (rock blocks). Other Transylvanian fortifications were constructed in a similar type (Gheorghiu, 1985). Cluj's fortifications were impressive, having an "extra-muros"-area of 45 hectares. Approximately 20 towers and gates were built by the Handmaids' Brotherhoods (Fig. 1) and used for defence during the periods of war.

Old documents refer to the strategy for the construction of the defence walls. The "city" used to pay the local and neighbourhood inhabitants for mining the limestone and to carry it by carts to the construction sites. Therefore, the limestone must have been excavated from the close vicinity of Cluj. Furthermore, several small quarries had to be opened because the huge mass of stones could not be quarried in one single quarry. Based on these assumptions, we focused the analysis on limestones occurring in the many small historical quarries around Cluj. Macroscopic and microfacies analyses of 
the building stones combined with mineralogical investigations (insoluble residue) indicate that Eocene (Cenozoic) limestones of different stratigraphic levels were used.
The main quarry for the construction was in Baci, near Cluj-Napoca where the basal strata of the Eocene limestone were excavated (Figs. 2A, B).

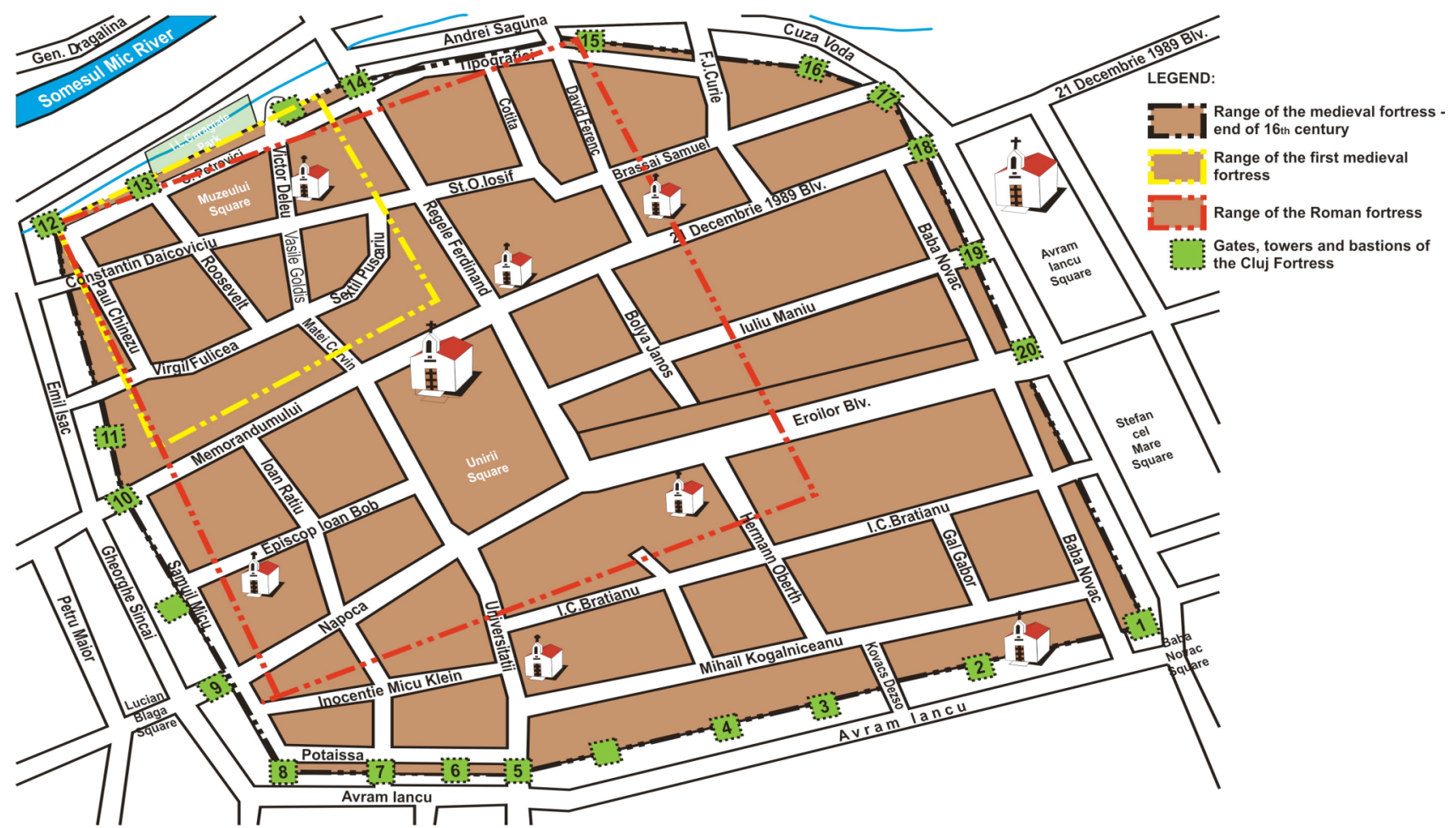

Fig. 1. Map of the Cluj Fortress with the localization of the walls, bastions, and towers at the end of $16^{\text {th }}$ century, acc. to Gheorghiu (1985). The location of the Roman Fortress is marked with a red dotted line and the first medieval fortress limit is marked with yellow dotted line. The Cluj Fortress covers about 45 ha.

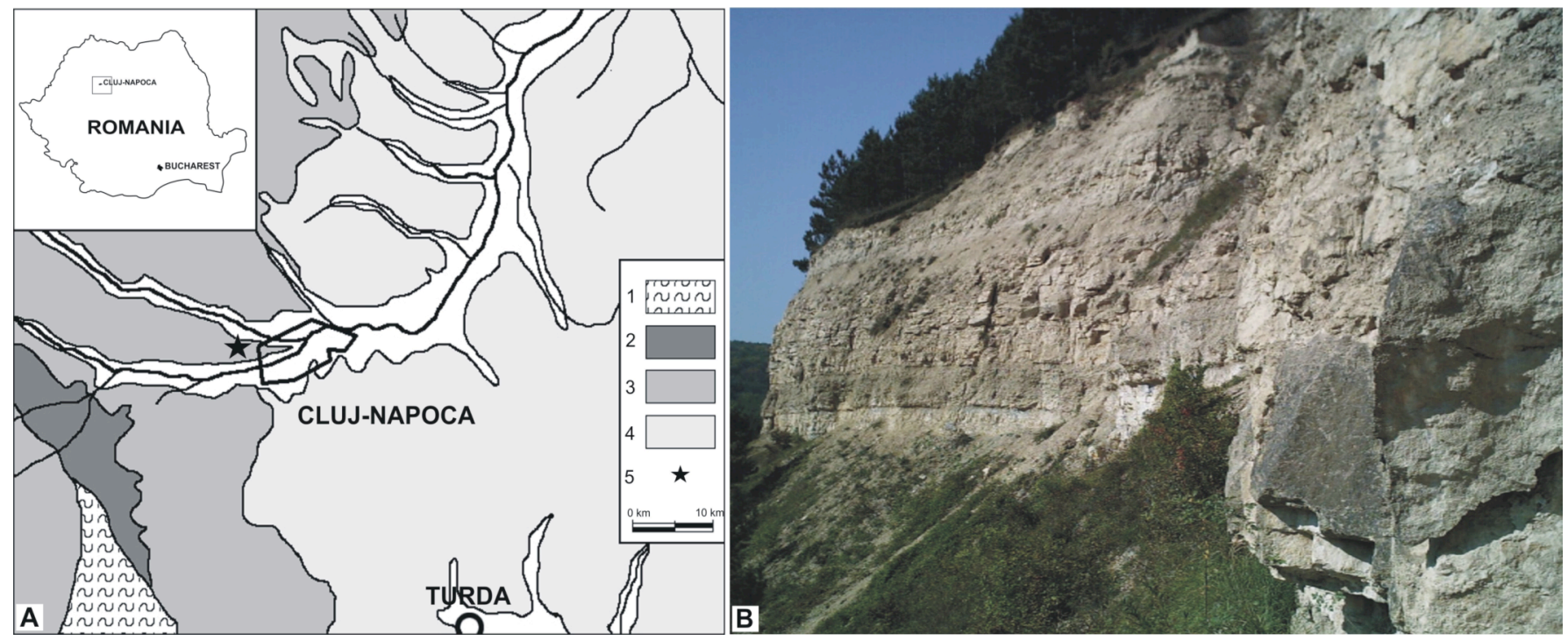

Fig. 2. A. The sketch map documenting the occurrence of Eocene limestones in the vicinity of Cluj-Napoca. Legend: 1 - Metamorphic rocks, 2 - Upper Cretaceous deposits, 3 -Paleogene deposits, 4 - Miocene deposits, 5 -Quarry (from Koch et al., 2008, based on Săndulescu et al., 1978); B. Panoramic view of the Baci Quarry.

The limestones were deposited on a shallow tropical carbonate platform in the Transylvanian Basin during the Late Eocene - Early Oligocene. The environment of deposition was influenced by episodes of terrestrial (siliciclastic) input from the surrounding area. Quartz, feldspar grains, and clay minerals were admixed to the carbonate sediment and among others are responsible for the white to yellowish colour of the limestones, its technical characteristics, and different types and degrees of weathering (Koch et al., 2008). Other rocks such as sandstones, clayey-sandstones, and manufactured bricks are also present within the wall as building stones in minor amounts.

\section{DISCUSSIONS}

The historical city wall of Cluj reveals remarkable damages due to intensive weathering of different Eocene limestone types depending on their primary facies types. In the first step, the damages had to be mapped by a method documented by Fitzner et al. (2002). This internationally 
accepted non-destructive method guarantees precise classification, registration, documentation, and evaluation of stone types and degradation phenomena at natural stone monuments. Damage mapping is the base for the calculation of all costs which will be necessary for the restoration of an historical monument.

Basic mapping and numbering, rock types mapping, weathering/damage mapping, relative humidity mapping, clash test mapping, fissures and cracks mapping, as well as mortar types and mortar damage mapping were carried out. Additional detailed mapping related to the weathering type processes will be developed. The basic mapping and the numbering correlated with the rock type and mortar type mappings give a detailed view on the walls architecture, construction, previous restorations, and varying rock type used in different amounts. The weathering/damage mapping combined with an index of weathering and damage processes results in a comprehensive list of all these processes. Moreover, the specific processes for each location can be differentiated by this method in relationship to the position above ground and exposition. The new method of index-mapping allows to synthesize the information and to create graphics that allow accurate conclusions on the development and causes of damages on a broad data base.

Moisture transport by capillary forces in the limestones of the city wall of Cluj is one of the most important parameters responsible for the formation of damages caused by intensive weathering. The smaller the pore diameter, the higher the moisture can migrate upwards. Thus, the intensity of the transport is directly dependent on the matrix content, porosity, and pore size of the different limestone facies types. During this process, cations from soluble components can also be transported from inside the rock to the surface resulting in the formation of crusts (Koch et al., 2008). Therefore, the mapping of the relative humidity at rock's surface helps in understanding the water circulations inside the wall and the different type of water accumulations (caused by capillarity force, by rain, or by the colonization of plants).

The complete moisture mapping for the city wall was achieved by hydrometer measurements. The lower part of the wall, up to $1-1.5 \mathrm{~m}$, is saturated with capillary water migrating upwards from the ground independent of the position of the wall. Combined with dust deposits, car exhaust pollutants, and salt solutions from the road the surfaces of the limestones are covered by various types of dark crusts. In contrast, the upper parts of the wall retain water predominantly from rain. Because of the plants and microbiological colonization, combined with the soiling by particles from the atmosphere, as well as with the domestic and industrial pollutants, black crusts are formed. Clash test mapping and fissures and cracks mappings give a preliminary view of the damage intensity inside the blocks, indicating the most affected areas which need special attention. The mortars type mappings combined with specific mineralogical analysis and macro- and microanalysis reveal four different types of mortars used throughout time. These mortars are differentiated by granulometry, components, binding, and colour. The determination of the E-Module (elasticity module) by the non-destructive method of measuring the dynamic resonance frequency also indicates three major mortar types: lime mortars, hydraulic lime, or cement mortar, and cement mortars.
The different facies types of limestones used as building stones for the Old City Wall of Cluj reveal different weathering features. These features are predominantly caused by the type of cementation (diagenesis), the amount and spatial distribution of porosity, the pore-geometry (effective and non-effective porosity), the amount of matrix and its microporosity, the amount of non-carbonates (clay minerals) in the limestones. In addition, the exposure and position of the stones in the wall and the moisture/dry cycles influence the degrees of weathering of the wall. Finally, the amount and composition of the fossils reflect the different limestone types exhibiting various weathering features. These parameters cause different and complex weathering processes which are reflected in the four groups of weathering types, "Loss of stone material", "Discoloration/Deposits", "Detachment", and "Fissures/ Deformation" as defined by Fitzner and Heinrichs (2004).

The limestone types of the city wall are composed predominantly of wackestones, packstones, and grainstones. Highly porous foraminiferal packstone (Plate I, Fig. 1) that contain common miliolids, minor mollusc shell debris, rare echinoid fragments, and well developed marine phreatic cements influences the rate of intensive weathering on the wall. The micrite is commonly re-crystallized to microspar and pseudospar. Additional cementation by granular and scalenohedral calcite is visible indicating a freshwater influx after the uplift of the sediments subsequently to the early marine cementation. The porous ooid grainstones (Plate I, Fig. 2) with common mollusc fragments, micritic lithoclasts, and some foraminifera (which form cores of ooids) are well cemented. Massive isopacheous rims with subsequently drusy mosaic are commonly visible. In these grainstones, weathering only results in dissolution of a few mollusc shells.

In porous and fractured oolitic packstone-grainstones (Plate I, Fig. 3) the cores of the ooids consist commonly of miliolids or other foraminifera and detrital quartz grains. Also, relics of isopacheous cement rims are visible. The micrite is usually re-crystallized to microspar. Small fractures indicate weathering predominantly due different thermal expansion (insolation) resulting in fractures running parallel to the surface of the stone. Different weathering phenomena can be recognized in highly porous foraminiferal wackestones-packstones (Plate I, Fig. 4). The micrite is heavily altered to microsparite and pseudosparite or completely dissolved. Even primary calcitic (Mg-calcite) fossil fragments are intensively re-crystallised. Furthermore, abundant biomolds of primary aragonitic biogenic allochems and vugs are formed.

A relative timing of the different mortars allows identifying mortars of different construction phases. Historical lime mortar, hydraulic lime (similar to historical mortar), and modern concrete mortar were used for the old city wall. The microscopic analysis of the mortar samples reveals different composition, porosity, and weatheringphenomena, giving important data about the quality. For example, the historical lime mortar (Plate I, Fig. 5) has a psammitic texture and a massive structure reflecting a portlandite microcrystalline matrix $(60 \%)$ with possible isotropic crystals as $\mathrm{Ca}(\mathrm{OH})_{2}$ (calcium hydroxide) and $3 \mathrm{CaO} \cdot \mathrm{Al}_{2} \mathrm{O}_{3}$ (tricalcic aluminate). This indicates that the mortar is probably originated from medieval times when pure lime was used. The hydraulic lime mortar is similar to the historical mortar (Plate I, Fig. 6), but reveals differences due to a different mortar manufacturing process. It is 
possible that quick lime was not completely transformed because of insufficient hydration, generating small cavities (pores or bubble-like vugs). Also, the mortars with bioclastic psammitic texture and massive structure have been identified (Plate I, Fig. 7). The modern mortar is represented by a mineral aggregate (Plate I, Fig. 8). The pores filled with portlandite indicate the hydraulic nature of the mortar.

\section{CONCLUSIONS}

The Old City Wall of Cluj-Napoca, Romania, is part of the former impressive Cluj's fortifications from the 16th century. Eocene limestone was used as the building stone. The analyses revealed remarkable damages due to the intensive weathering. The presence of these complex processes required macroscopic and microfacies analyses of the building stones combined with mineralogical investigations. All the stones used were indexed together with their complex damages by mappings and indexing models, which allow additional calculation of all the necessary costs for the restoration of the wall. Large parts of the wall need special attention and urgent restorations. Further detailed analyses are recommended for the adequate restoration proposals.

\section{R E F E R E N C E S}

Fitzner, B., Heinrichs, K. \& La Bouchardiere, D. 2002, Damage index for stone monuments. In: Protection and conservation of the cultural heritage of the Mediterranean cities (Galan, E., Zezza, F., Eds.), Proceedings of the $5^{\text {th }}$ International Symposium on the Conservation of monuments in the Mediterranean Basin, Sevilla, Spain, 5-8 April 2000, Swets \& Zeitlinger, Lisse, p. 315-326.

Gheorghiu, T.O. 1985, The defence medieval architecture from Romania. Ed. Tehnică, Bucureşti, 133 p. (in Romanian).

Koch, R., Răcătăianu, P.C. \& Bucur, I. 2008, Examples of weathering and deterioration of Tertiary building stones at St. Michaels Cathedral in Cluj-Napoca (Romania). Studia Universitatis Babes-Bolyai, Geologia, 53 (2): 25-39.

Săndulescu, M., Kräutner, H.G., Borcoş, M., Năstăseanu, S., Patrulius, D., Ştefănescu, M., Ganea, C., Lupu, M., Savu, H., Bercia, I. \& Marinescu, F. 1978. Geological map of Romania, 1:1,000,000. Geological Institute of Romania, Bucharest. 


\section{Plate I. Microscopic images of damages.}

Fig. 1. Highly porous foraminiferal packstone with common miliolids and other foraminifera, minor mollusc shell debris, and rare echinoid fragments. Intensive weathering is indicated by the micrite, which is commonly re-crystallized to microspar and pseudospar. Additional cementation by granular and scalenohedral calcite occurred. The intense blue colour is due to the pigment added for enhancing the pores.

Fig. 2. Porous ooid grainstone with common mollusc fragments, micritic lithoclasts, and some foraminifera, which form cores of ooids. Limestone is well cemented and stable (isopacheous rims; subsequently drusy mosaic are commonly visible). Weathering only results in dissolution of some mollusc shells.

Fig. 3. Porous and fractured oolitic packstone-grainstone with cores of ooids formed by common miliolids, other foraminifera, and detrital quartz grains. Relics of isopacheous cement rims and micrite (commonly re-crystallised to microspar) are visible. A predominant result of weathering is the formation of fractures parallel to the surface of the stone (variable thermal expansion or insolation).

Fig. 4. Highly porous foraminiferal wackestone-packstone. The micrite is heavily altered to microsparite and pseudosparite or completely dissolved. The fossil fragments are commonly re-crystallised. Abundant biomolds and vugs are visible.

Fig. 5. Mortar with sub-angular detritic fragments (approx. 40\%), represented by quartzite (Q), quartzite with muscovite (Qm), lamellar muscovite (Mu), microcline (M), perthite fragments (Per). The microcrystalline matrix (Ma) containing portlandite ranges up to $60 \%$. The texture is psammitic and the structure is massive. $N+$

Fig. 6. Mortar with detrital fragments of quartz $(Q)$ bound in matrix (Ma). Inside the matrix, portlandite with micro-granular aspect and double-refractive colours are visible. Microcrystalline silica (Si) is present inside a pore lined with portlandite (Por). $N^{+}$

Fig. 7. Mortar with detrital fragments of quartz (Q), limonitized quartzite (Qlim), muscovite (Mu), and bioclastic relicts (Bio) bound inside the matrix (50-55\%) (Ma). The texture is bioclastic psammitic and the structure is massive. $\mathrm{N}+$

Fig. 8. Modern concrete mortar as a mineral aggregate composed of quartz (Q) (approx. 30\%) and microcrystalline matrix (Ma) (70\%), which contains small isotropic crystals of calcium aluminate(?) or calcium oxide(?). Inside the matrix the micro-granular portlandite and double-refractive colours dominates. Pores walls lined with portlandite (Por) are visible. $\mathrm{N+}$ 
PLATE I
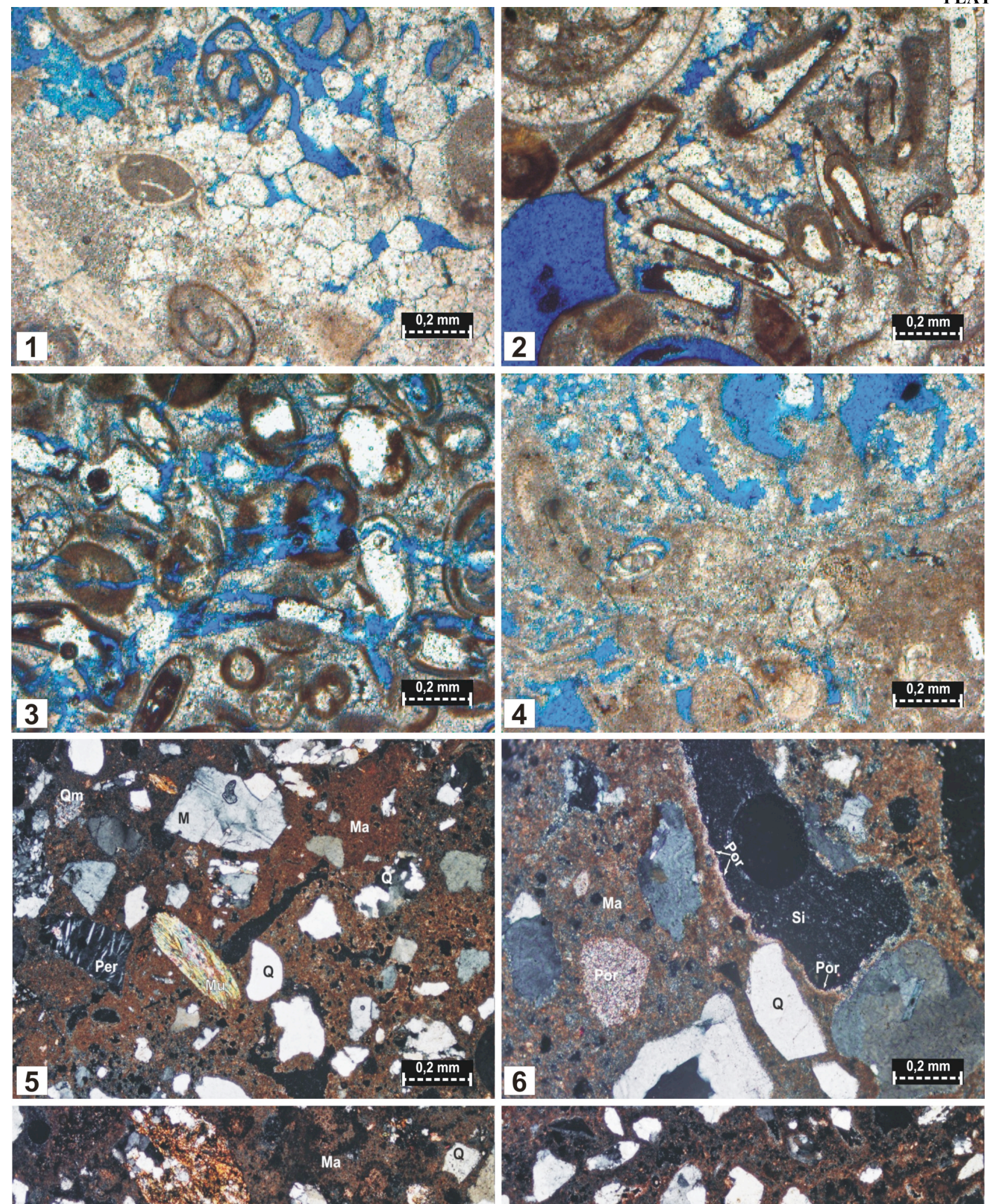

4.24 a

104. 5 , 3

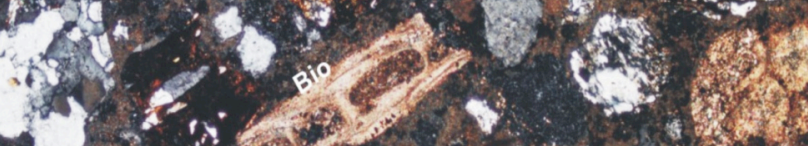

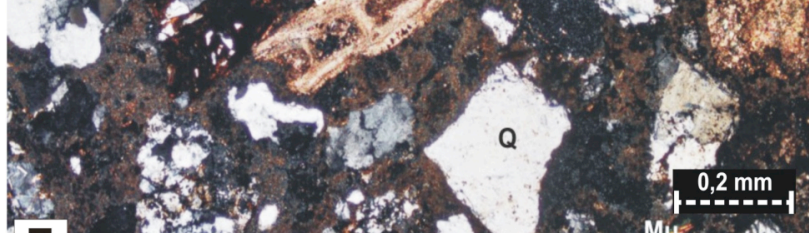

7 .

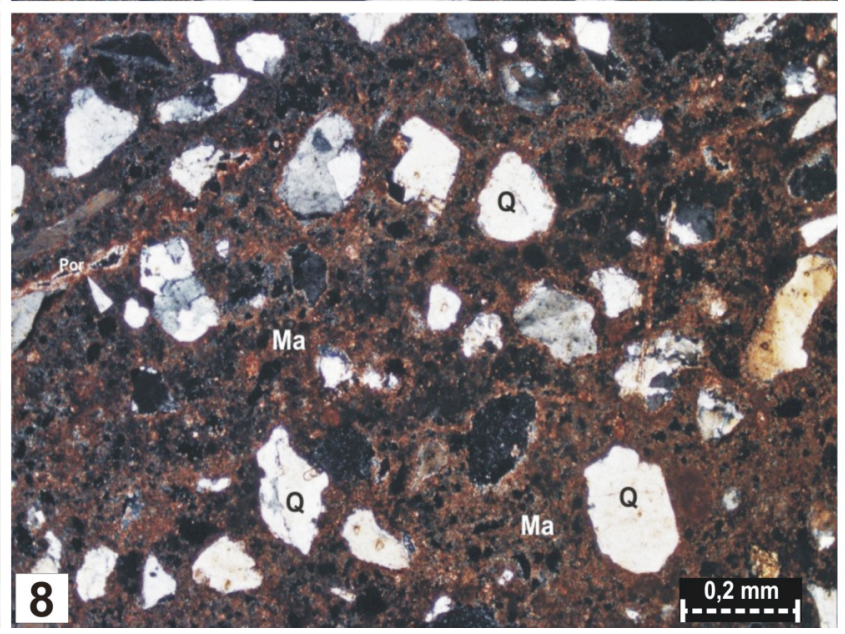

